\title{
Comprehensive Guidance and Counseling Programs in Developing Student Talent
}

\author{
Lestari $^{\mathrm{a}}$, Rita Eka Izzaty ${ }^{\mathrm{b}}$ \\ ${ }^{a}$ Pascasarjana Universitas Negeri Yogyakarta \\ ${ }^{\mathrm{b}}$ Pascasarjana Universitas Negeri Yogyakarta \\ e-mail: lestari.124@yahoo.coma
}

\begin{abstract}
This article provides an overview of multicultural competencies from a global perspective, specifically as it relates to counseling students in Indonesia. An overview will be given of the cultural interactions observed by counselor educators who were visiting professors at a university in Indonesia. While racial and ethnic diversity in countries such as Indonesia remain homogenous, cultural differences were noted with respect to the intersectionality of gender and disability. The intersection of culture, gender, and disability present unique challenges for counselors trying to assist their clients. Thus, it is imperative that counseling students become culturally competent so they can assist their clients who come from varying backgrounds. Implications are given to counseling programs to increase their students' multicultural competencies when working with global populations.
\end{abstract}

\section{Keywords: Multicultural Competence, Intersectionality, Privilege, Counseling, Indonesia}

\begin{abstract}
Pendidikan merupakan upaya dalam mencerdaskan generasi bangsa. Seorang individu pertama kali mendapatkan pendidikan di lembaga keluarga, kemudian mereka melanjutkan pada lembaga pendidikan yang bersifat formal yaitu lembaga sekolah. Sebagian besar siswa memandang bahwa sekolah merupakan lembaga yang dapat membantu dalam menggapai cita-cita. Dalam membantu dan mendukung tercapainya sebuah cita-cita, maka siswa diharapkan memiliki kemampuan baik secara akademik maupun non akademik. Seorang siswa yang ingin menggapai citacita tidak terlepas dari bakat yang dimiliki. Namun, tidak semua siswa mengerti akan bakat yang mereka miliki. Hal tersebut nampaknya tidak terlepas dari peran konselor sekolah dalam mengembangkan bakat siswa. Konselor memiliki peran dalam membantu siswa menumbuh kembangkan potensi yang dimilikinya. Lebih lanjut upaya yang dilakukan konselor sekolah dengan memberikan program bimbingan dan konseling komprehensif atau lebih sering disebut dengan BK komprehensif. Terdapat empat komponen penting dalam program BK komprehensif yang meliputi: layanan dasar, layanan responsif, perencanaan individual, dan dukungan sistem. Selanjutnya ada berbagai pengembangan bakat siswa yang meliputi: pengembangan visual, penalaran angka, verbal, urutan gambar, spasial, tiga dimensi, sistematisasi, kosakata, dan figural angka. Diharapkan dengan adanya pemberian program BK komprehensif, sehingga siswa dapat memahami dan mengembangkan bakat yang dimiliki.
\end{abstract}

\section{Kata Kunci: Bimbingan dan Konseling Komprehensif, Bakat Siswa}

\section{INTRODUCTION}

Over the next 50 years, the population of the United States will become increasingly diverse. Therefore, it is imperative that counselor educators are culturally competent and prepare students to work with varying populations that are inclusive of race, gender, religion, ethnicity, and disability. It is equally imperative that students are prepared for the everchanging demographic landscape and are able to understand and acknowledge the importance of fostering a deeper awareness of cultural relevancy.

With the increased demand for globalization, it is important for counseling professionals to become culturally competent when working with international populations. According to the Open Doors Report of 2016, more than one million international students studied at U.S. colleges and institutions in 2015/2017, with $60 \%$ of those students coming

DOI : https://dx.doi.org/10.26486/ijagc.v1i2.1188

URL : http://ejurnal.mercubuana-yogya.ac.id/index.php/IJAGC/index

Email: ijagc@mercubuana-yogya.ac.id 
from China, India, Saudi Arabia and South Korea. Wu, Garza \& Guzman (2015) stated that international students contribute to the diversity of classrooms, universities and communities, and their diversity should be embraced as they bring unique ways of thinking to the academic environment. Hence, global partnerships are of utmost importance and aid in increasing competencies for counselors in the U.S. and abroad.

\section{Becoming Culturally Competent}

The process of becoming culturally competent requires that individuals acknowledge that it's important for one to investigate their own cultural heritage, pay attention to the influence of privilege on their understanding of cultural issues, educate themselves through diverse sources of information, develop diverse relationships, and understand the influence of sociocultural contexts (Sue \& Sue, 2008). Understanding cultural values requires that one has information about the group including having exposure to a variety of individuals within the group. Additional requirements include understanding the sociopolitical dynamics of justice, oppression, history, and self-awareness as well as an understanding of how age, geographical location, ethnicity, and physical ability mediate the influences of culture. In order to become culturally competent, one must recognize that all human beings have the capacity for thought, feeling, and behavior. They must also be knowledgeable in several cultures, study differences and similarities of different groups, and gain an understanding and appreciation of what motivates others in how they form their world view. Finally, they must cultivate understanding and awareness of their own cultural influences (Sue \& Sue, 2008).

\section{The Role of Privilege}

Privilege is defined as "a right or immunity granted as a peculiar benefit, advantage, or favor: prerogative especially such a right or immunity attached specifically to a position or an office. An advantage that only one person or group of people has, usually because of their position. (Merriam-Webster)

Why does privilege matter? Because 1) it sets the foundation for what we think about ourselves and others; 2) it can contribute significantly to a person's opportunities; and 3) it can influence a person's perception of who they are and what they can do. Racism, sexism, ageism, ableism, heterosexism, and classism are invisible to the majority for several reasons: 1) they do not personally experience it; 2) their challenges are not attributed to race, gender, age, sexual orientation, disability, and class; 3) they do not see, or perceive, what others experience.

\section{Counseling International Students}

Having international students in classrooms present opportunities for enrichment for both students and faculty at U.S. institutions. Students matriculating at universities in the U.S. and internationally can benefit from exposure to different values, beliefs and traditions thereby increasing cultural competency and constructing a diverse worldview (Wu, Garza \& Guzman, 2015). Consequently, engaging in global partnerships between the U.S. and Indonesia that allow students and faculty to experience different cultures, enlarges their worldview.

\section{View of Disability in Asia}

Asia consists primarily of collectivist cultures that focus on family and community goals. These values are often in contrast to individualistic cultures seen in the U.S., Canada, and Western European countries where the focus is more on competition and achievement. While there are diverse cultures in Asia, many countries hold in high esteem, values such as respect, social order, harmony, and peaceful relations among society (Chun et al., 2016; Yan 
et al., 2014). Many of these values are attributed to and informed by eastern and religious philosophies of Confucianism and Taoism (Yan et al., 2014), as well as Hinduism, Islam, Sikhism, and Buddhism (Anees, 2014). Due to the varying worldviews, disability is sometimes regarded as at odds, and in opposition to the family structure, and is therefore subject to ridicule, prejudice, and marginalization by other members of Asian societies (Yan et al., 2014). In South Korea and India, some people believe that supernatural forces cause disability, or that disability is a punishment or atonement of sins from past lives (Anees, 2014; Yan et al., 2014).

\section{Intersectionality of Disability}

According to The World Health Organization (WHO; 2018) approximately one billion, or $15 \%$ of the world's population are living with a disability around the globe. Disability prevalence is higher for developing countries. One-fifth of the estimated global total, or between 110 million and 190 million people, experience significant disabilities. WHO (2018) further stated that disability rates will continue to increase due to the growing number of chronic illnesses and conditions in addition to older adults living longer.

Emerson (2011) documented that disability is a global, human rights issue and further noted that PWD encounter considerable barriers when accessing community services. Emerson (2011) further identified that disability rates disproportionately affect women and children around the world and PWD have worse health and socioeconomic outcomes than those not living with disabilities. Globally, children and youth with disabilities are either not enrolled in school, never complete their education, or they are denied educational accommodations for their disabilities (Chun et al., 2016).

United Nation's (U.N.) Department of Economic and Social Affairs on Disability (2019) reported that only 45 countries have anti-discrimination and disability-related laws. Further work is necessary to ensure that PWD are protected and afforded equal access to community, work, education, and living.

\section{Disability in Indonesia}

Disability affects many lives in Indonesia. There are approximately 10 million people with some form of disability. Prevalence data indicates that disability represents $4.3 \%$ of the population and based on the latest census data that number is believed to be understated. Forty percent of those who have a disability have multiple disabilities (WHO, 2019).

Rakhmat \& Tarahita (2017) reported that resources designed to benefit people with disabilities (PWD) have been under discussion for a considerable time in Indonesia. They further reported that services, facilities, and budgets are inadequate to meet the health, education, and employment needs of PWD. There are few legal and social resources available to advocate for non-discriminatory practices on behalf of PWD (Rakhmat \& Tarahita, 2017).

Officials in Indonesia have made attempts to provide accessible services for PWD, however, they have not been successful in achieving accessibility in public accommodations to the magnitude as services that are provided in the U.S. through the Americans with Disabilities Act (ADA). One controversial policy sought to ban an online public transportation booking system that operates in several major cities in Indonesia. In general, public transport facilities are inadequate for PWD. Hence, people with mobility issues find transportation services remain limited. Having access to online transportation booking offers a safe, economic, and convenient alternative for PWD who otherwise would have to access more expensive offline services. Another example of the government not fulfilling the needs of PWD is the civil servant entrance exams; that are made up primarily of pictures. Using these types of exams tend to discriminate against the blind, the biggest disability population in Indonesia (Rakhmat \& Tarahita, 2017). 
According to Kusumastuti, Pradanasari, \& Ratnawati (2014) people with disabilities in Indonesia often live with high rates of poverty. Approximately 1.8 percent of PWD have "extreme problems", while 19.5 percent of PWD have "problems". Commonly held prejudicial beliefs about PWD are that they are unproductive and dependent.

Ratts and Pedersen (2014) incorporated the biopsychosocial approach with the counselor-advocate-scholar (CAS) model. This model purports that the role counselors assume to deliver services to assist their clients is dictated by context (i.e., counselor advocate, scholar). Additionally, the model posited that counselors should give attention to addressing the systemic and oppressive barriers that may interfere with their client's functioning (Ratts \& Greenleaf, 2018). This model may be beneficial when working with marginalized groups, such as PWD disabilities to assist them in attaining satisfaction and quality of life. The model asserts that counselors should assist their clients in making appropriate life choices based on culturally and personally appropriate options, whether differences exist related to disability, gender, or other areas or not.

\section{Intersectionality of Gender}

Gender plays a key role in one's perception of privilege, power, and oppression (Enns et al., 2005). Shields (2008) stated that the intersectionality perspective "further reveals that the individual's social identities profoundly influence one's beliefs about and experience of gender" (p. 301). In order to understand a person's unique life experiences, we must acknowledge multiple, interconnected social identities (e.g. gender, race) and how said identities inevitably influence development as a counselor or counselor educator. For example, an Indonesian woman may be categorized as "Asian", "woman", or both. Social categories or intersecting identities may provide certain advantages or disadvantages across genders (Himmelstein et al., 2017).

Regarding gender, it is particularly meaningful to have the social, political, economic, and legal context for cases of opportunity, discrimination, marginalization, and violence (Sharples, 2018, March 8). The context of gender in both Indonesia and America is structural, intersectional, and provides insight into day-to-day expectations of students and educators. For instance, American sociologist Arlie Russell Hochschild (1989) coined "the second shift," a term which refers to working women being more likely to return home at the end of their workday expected to perform unpaid household labor such as cleaning, food preparation, and caregiving for children and other family members. Expectations based on gender identity are further complicated by race, ethnicity, class, culture, ability, age, affectional identity, and education among other forms of social category. Though gender does not automatically determine any particular experience for a counselor or counselor educator, it certainly provides context for what unique challenges a person may or may not be faced with in their country, career, and personal relationships, consequently impacting the counselor education training process.

\section{Counselor Educators' Perspectives}

As educators, it is crucial to be aware of how our intersecting identities influence our instructional roles, positionalities, and interactions with students (Enns et al., 2005). It was critical that we as visiting professors were aware of the goals of our students in Indonesia, prevalent issues counselors may face in that region, and recognition of cultural differences that would inevitably arise in the classroom. Of equal importance is for counselor educators to embrace the diversity that international students contribute to the classroom by way of their cultural and academic experiences, and economic influences (Wu, Garza \& Guzman, 2015).

Wu, Garza, and Guzman (2015) conducted a meta-analysis of research on counseling 
international students and found that international students across the country and in other countries experienced significant levels of stress. In the U.S. many international students experienced language difficulties, difficulties adjusting to the academic culture, communication issues with professors and peers, lack of appropriate accommodation, culture shock and feelings of loneliness and isolation. Agreement was shared by the students that adjusting to life in the U.S. created challenges as did being taught by U.S. professors. Students reported that some of the similar feelings arose with respect to feeling a sense of inferiority, while taking our classes even though they were in their home country.

It was evident to the authors that the students in Indonesia were experiencing a great deal of stress related to language barriers. As such, many of the students who were fluent in English stated they preferred to have an interpreter speak for them even though we advised them that we understood what they were saying. The process of reassuring students that their language was understandable was done by the counselor educators throughout the visit in all of the classes.

Students shared during the classes that they wanted to be viewed favorably by the instructors and did not want to say something that could be misinterpreted. They shared that education was valued in their country and they wanted to present themselves in the best light. The counselor educators made a point to spend time during the beginning of each class engaging students in conversations that made them feel at ease when introducing various concepts.

\section{Classes}

The authors were invited to serve as visiting professors for a counselor education program in Indonesia and taught four unique courses for graduate and undergraduate students. The first course titled "Communicating with Individuals with Disabilities: People First Language" addressed disability statistics in Indonesia and the United States, the power of language regarding stereotypes and diagnoses in people with disabilities, examples of appropriate and inappropriate language for work with this population, and how we as counselors can help or hinder our clients with disabilities.

Students were taught that words have power! The words we use to describe people can either be uplifting and encouraging or degrading and dehumanizing. Words shape the attitudes and beliefs of society and influence our world. Further we discussed how people with disabilities (PWD) constitute the largest minority group in the United States and it is the only minority group comprised of all genders, races, age groups, socioeconomic levels, and religions. This minority group is not exclusive; anyone can join this group at any time.

Students engaged in conversations about global disability statistics and became familiar with global data that suggests that $15 \%$ or the world's population has a disability (over one billion people), the world's largest minority group is comprised of PWD, $82 \%$ of PWD come from developing countries (lack access to education, healthcare, jobs), 785 million PWD are working age but do not have jobs, $4.3 \%$ of Indonesians have a disability (10 million people), and finally that in 2016, The Law on Disability passed stating PWD must have equal rights.

The course was well received, and students indicated that they were not familiar with the materials and had not received previous exposure to the materials presented or the manner in which they were presented. Students acknowledged that disability is viewed differently in their country and they appreciated learning about ways to increase their competencies when working with people with disabilities. People with disabilities generally are not a part of society and Indonesia lags behind the United States with regard to accommodating disabilities.

The second course titled "Counseling Globally: Promoting Peaceful Societies" 
addressed counseling international students in the United States, common stressors and unique needs of international students globally, becoming culturally competent counselors, and recommendations for promoting peaceful societies. Students engaged in a discussion about terms that are associated with cultural competency such as oppression and that it happens at all levels, reinforced by societal norms, institutional biases, interpersonal interactions, and individual beliefs. Additionally, they discussed social justice which is the idea of acting with equality, fairness and dignity to all human beings that follows the principle that all individuals and groups are entitled to fair and impartial treatment.

Students were taught that in order to become culturally competent, one must recognize that all human beings have the capacity for thought, feeling, and behavior. They must also be knowledgeable in several cultures, study differences and similarities of different groups and gain an understanding and appreciation of what motivates others and how they form their world view. Finally, they must cultivate understanding and awareness of their own cultural influences (Sue \& Sue, 2008). Students were taught that the role of a culturally competent counselor is a collaborative effort with the client whereby the counselor helps to identify personal, social, or career problem areas to determine counseling goals by paying attention to the client's needs rather than basing decisions upon assumptions related to the client's race, ethnicity, religion, gender, sexual orientation, age, disability status, social economic status, or intellectual ability. Further, techniques are implemented for behavioral change based upon client need and not upon the values and biases of the counselor. The counselor facilitates the development of a personal

relationship that provides a climate for the client to expand self-awareness, explore possibilities for growth, learn new skills, and achieve a better understanding of their environment (Sue \& Sue, 2008).

The third course titled "Working with Children with Mental Health Issues" addressed prevalence of mental health concerns and disabilities in both American and Indonesian children, contextual influences on a child's mental health (e.g. family and home life, cultural beliefs and values, child maltreatment, grief and loss, divorce, genetics, self-confidence, bullying, etc.), and specific interventions for counseling children.

Statistical information was shared to help expand students' knowledge when working with children as several of the students worked in schools and were interested in increasing their knowledge in this area. Some of the materials presented concerned children and mental health in the U.S.; specifically, 1 in 5 children ages 13-18 have, or will have a serious mental illness, $20 \%$ of youth ages 3-18 live with a mental health condition, $11 \%$ of youth have a mood disorder and $70 \%$ of youth in state and local juvenile justice systems have a mental illness.

Children with disabilities in Indonesia are eligible to participate in inclusive education, however some of them do not get accepted into mainstream education because of entry test requirements. Worldwide, $10 \%$ of youth have a behavior or conduct disorder, approximately $50 \%$ of students age 14 and older with a mental illness drop out of high school, $8 \%$ of youth have an anxiety disorder, suicide is the 3rd leading cause of death in youth ages $10-24$ years of age and $90 \%$ of those who died by suicide had an underlying mental illness. According to WHO (2011), 10-20\% of children and adolescents experience mental disorders. Half of all mental illnesses begin by the age of 14 and three-quarters by mid-20s.

Neuropsychiatric conditions are the leading cause of disability in young people in all regions. If untreated, these conditions severely influence children's development, their educational attainments, and their potential to live fulfilling and productive lives. Children with mental disorders face major challenges with stigma, isolation and discrimination, as well as lack of access to health care and education facilities, in violation of their fundamental 
human rights. Statistics such as this, attest to the need for urgency in advocating for children with disabilities in Indonesia and throughout the world (WHO, 2011).

The fourth course titled "Intersectionality: Culture and Career Decision Making" addressed understanding privilege, cultural competence, the influence of culture on career decision-making, and the Sociological Theory of Career Development. This course also involved a privilege walk intervention. Students learned that from a sociological perspective, that an emphasis on external (system) factors (economics, social class, cultural background, gender) influence career development. Additionally, they learned that societal circumstances beyond the control of the individual contribute significantly to career choices and the principal task confronting a person is the development of techniques to cope effectively with the environment.

\section{Privilege Walk}

To begin conversations surrounding privilege, counseling students at an Indonesian university were given the opportunity to participate in an exercise using physical space to visualize their positionality and the positionalities of their classmates. According to Sassi and Thomas (2008), the objective of the privilege walk intervention is to help students understand the nature of privilege. During this multicultural competence exercise, students line up across the middle of a room, the facilitator reads a series of statements, and students take steps forward or backward depending on whether the statement applies to them. For example, the facilitator may say "take one step forward if your parents are university educated." Essentially, the further from the starting point a person is, the more privilege they possess.

The privilege walk exercise was developed by the National Training and Curriculum Institute. The objective of the exercise is to assist participants in seeing and feeling the inequities many people face. The only props necessary are the Activity Statements. The privilege walk exercise can be altered to be more appropriate for certain populations or classrooms. Privilege is a universal concept but may look different across cultures. As visiting professors from the United States, there were several observed differences in student responses to the privilege walk intervention when comparing American and Indonesian students. Typically, American students are more likely to address differences in privilege based on race and ethnicity because the country is so racially and ethnically diverse, whereas Indonesia is a less racially and ethnically diverse country and students focused more on gender and class. Additionally, American counseling students seemed more willing to discuss privileges surrounding disability and affectional identity than students in Indonesia. Indonesian counseling students acknowledged class and gender concerns during the privilege walk more readily than many counseling students in the United States. During this exercise in Indonesia, we noticed that the majority of students were more eager to reach the "finish line" and more likely to keep instances of oppression or disadvantage private. Following the privilege walk exercise, a large portion of students admitted that they felt "embarrassed" and did not feel comfortable addressing their privilege or lack of privilege in front of their peers during the intervention, but were willing to talk about it during a group processing session afterward. Students further indicated that they lacked knowledge about PWD because they are not readily seen in public due to accessibility issues. Lastly, they indicated that there are different gender expectations in Indonesia, so they do not really think about it or address it in the same manner as their U.S. counterparts.

\section{METHODS}

This article is a literature review, mainly from research results and also analysis of issues related to scientific references. The study provides an explanation of some of the 
meanings of the variables raised in this article. The type of data used by the author in this study is primary data by observing and secondary data, namely data obtained from journals, books, documentation studies, and online references. The data that has been obtained is then analyzed by descriptive analysis method. Descriptive analysis method is done by describing the facts which are then followed by the analysis, not merely describing, but also provides sufficient understanding and explanation.

\section{FINDINGS AND DISCUSSION Findings}

While working with counselor education students in Indonesia, there were several observations made. Students and professors in Indonesia were incredibly accommodating to our language barriers and made themselves available to interpret for us at any time since we are fluent in English only. Our students were able to speak both English and their native languages and thrived when they were able to listen to our lectures in both languages thanks to a translator. Though translation required more time, it allowed us and our students to have more productive conversations. Students were able to focus on the content of the lectures rather than worry if they were interpreting the content accurately.

Teaching these courses in Indonesia was significantly different than teaching these courses in the United States. Indonesian students asked more questions during class than some American students. Whereas, American students seemed more likely to present their ideas as discussion topics during class as opposed to presenting those ideas as questions. Anecdotally, counseling students in Indonesia were incredibly kind and respectful to professors and fellow students and our work with them was a pleasure. And as such, we will continue to form partnerships such as this where the two cultures can interact. It is our hope that we can return to Indonesia again in the future and continue our collaboration. Similarly, we would like for faculty and students to matriculate at our institution. We were fortunate to see this global collaboration come to fruition when one of the faculty from Indonesia entered our doctoral program this year. Additionally, one of the visiting professors became a reviewer for one of the international journals in Indonesia. We welcome future global collaborations.

\section{Discussion}

First, counseling programs should continue to collaborate with American universities and expose their students to professors who come from diverse backgrounds. Having these types of diverse experiences allows counseling students the opportunity to develop crosscultural competencies that will benefit their clients. Secondly, counseling programs are encouraged to seek funding for programs whose mission is to help increase cultural competencies of counselors who work with various underprivileged and underrepresented populations. Thirdly, counseling programs should strive to make student, faculty, and staff exchanges a priority. And finally, counseling programs should continue to promote global partnerships that demonstrate their commitment to diversity.

\section{CONCLUSION}

The need for cultural competence has been elucidated earlier. Living in a pluralistic world requires moving beyond cultural encapsulation. Self-awareness is the first tier of multicultural competence and the foundation that knowledge and skills are built upon. Selfawareness is not an automatic process. Self-awareness takes a conscious effort, energy, persistence, and most importantly, the willingness and ability to experience and discuss intense emotions while striving to understand our emotional reactions (Sue \& Sue, 2008). There is much work to be done in Indonesia as PWD and women still experience; whether intentional or not; a level of marginalization and discrimination against them. Hence, the 
university is commended for supporting the counseling program in these collaborative efforts that promote peace and increase cultural competencies.

Counseling students from Indonesia were able to gain valuable lessons that will continue to guide them in increasing their own cultural competencies, particularly as it relates to persons with gender differences and people with disabilities (PWD). It is our hope that these types of global partnerships will continue with students and faculty traveling to the U.S. in the future.

\section{REFERENCES}

Anees, S. (2014). Disability in India: The Role of Gender, Family, and Religion. Journal of Applied Rehabilitation Counseling, 45(2), 32-28.

Chun, J., Connor, A., Kociulek, J. F., Landon, T., \& Park, J. (2016). Career development for youth with disabilities in South Korea: The intersection of culture, theory, and policy. Global Education Review, 3(3).

Disability in Indonesia: What can we learn from the data? www.monash.edu > _data > asset>retrieved from https://www.asiasentinel.com/p/indonesia-disability-issues-lackdata

Emerson, E. (2012). The World Report on Disability. Journal of Applied Research in Intellectual Disabilities, 25(6), 495-496. https://doi.org/10.1111/j.14683148.2012.00693.x

Enns, C. Z., Sinacore, A. L., Acevedo, V., Akçali, Ö., Ali, S. R., Ancis, J. R., ...Tao, K. W. (2005). Integrating multicultural and feminist pedagogies: Personal perspectives on positionality, challenges and benefits. In C. Z. Enns \& A. L. Sinacore (Eds.), Teaching and social justice: Integrating multicultural and feminist theories in the classroom (pp. 177-196). Washington, DC: American Psychological Association.

Himmelstein, M. S., Puhl, R. M., \& Quinn, D. M. (2017). Intersectionality: an understudied framework for addressing weight stigma. American Journal of Preventive Medicine, 53(4), 421-431. https://doi.org/10.1016/j.amepre.2017.04.003

Hochschild, A. R., \& Machung, A. (1989). The second shift: working parents and the revolution at home. New York, N.Y.: Viking.

Institute on International Education (IIIE), (2016). Open Doors "Fast Facts". Available at www.iiie.org/opendoors

Kusumastuti, P., Pradanasari, R., \& Ratnawati A. (2014). The problems of people with disability in Indonesia and what is being learned from the World Report on Disability. Am J Phys Med Rehabil. 2014;93(1 Suppl 1):S63- S67. doi:10.1097/PHM.0000000000000025

Merriam-Webster Dictionary (2020). Retrieved May 20, 2020 from: https://www.merriamwebster.com/dictionary/privilege

Rakhmat, M. \& Tarahita, D. (2017). Disability Issues and the Lack of Data in Indonesia. Asia Sentinel. Retrieved from: https://www.asiasentinel.com/p/indonesia-disabilityissues-lack-data 
Ratts, M. J., \& Greenleaf, A. T. (2018). Counselor-advocate-scholar model: Changing the dominant discourse in counseling. Journal of Multicultural Counseling and Development, 46(2), 78-96. doi: 10/1002/jmcd.12094

Sassi, K., \& Thomas, E. E. (2008). Walking the talk: Examining privilege and race in a ninthgrade classroom. English Journal, 25-31. https://www.jstor.org/stable/40503407

Sharples, M. (2018, March 8). Gender, development, and the challenge of intersectionality. Oxfam. intersectionality/ https://views-voices.oxfam.org.uk/2018/03/gender-development-

Shields, S. A. (2008). Gender: An intersectionality perspective. Sex Roles, 59(5-6), 301-311. https://doi.org/10.1007/s11199-008-9501-8

Sue, D. W., Arrendondo, P., \& McDavis, R. J. (1992). Multicultural counseling competencies and standards: A call to the profession. Journal of Counseling \& Development, 70, pp. 477-486.

Sue, D. W., \& Sue, D. (2008). Counseling the culturally diverse: Theory and practice. (5 Ed.). Hoboken, New Jersey: John Wiley \& Sons, Inc.

United Nations (2019, November 30). Department of Economic and Social Affairs on Disability. https://www.un.org/development/desa/disabilities/

Wu, H., Garza, E., \& Guzman, N. (2015). International student's challenge and adjustment to college. Education Research International, https://doi.org/10.1155/2015/202753

World Health Organization. (2001). International classification of functioning, disability and health: ICF. Geneva: World Health Organization.

World Health Organization. (2011). World report on disability. Available at: www.who.int.Accessed May 25, 2020.

World Health Organization (2019, November 30). Disability. https://www.who.int/disabilities/en/

Yan, K. K., Accordino, M. P., Boutin, D. L., \& Wilson, K. B. (2014). Disability and the Asian culture. Journal of Applied Rehabilitation Counseling, 45(2), 4-8. 